\title{
In vitro lytic efficiency of Staphylococcus aureus bacteriophages in bacteria from bovine mastitis: a meta-analysis
}

\section{Bibiana Martins Barasuol ${ }^{1}$ (i) Valessa Lunkes Ely ${ }^{1}$ (i) Antônio Francisco Igor Magalhães de Matos $^{1}$ (i) Luis Antônio Sangioni ${ }^{1}$ (i) Agueda Castagna de Vargas $^{1}$ (i) Daniela Isabel Brayer Pereira ${ }^{2}$ (i)

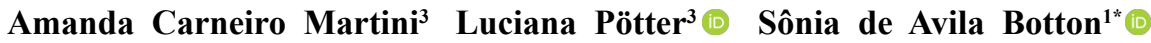

${ }^{1}$ Departamento de Medicina Veterinária Preventiva (DMVP), Programa de Pós-graduação em Medicina Veterinária (PPGMV), Centro de Ciências Rurais (CCR), Universidade Federal de Santa Maria (UFSM), 97105-900, Santa Maria, RS, Brasil. E-mail: sabott20@gmail.com. ${ }^{*}$ Corresponding author.

${ }^{2}$ Instituto de Biologia, Departamento de Microbiologia e Parasitologia, Universidade Federal de Pelotas (UFPel), Pelotas, RS, Brasil. ${ }^{3}$ Departamento de Zootecnia, Centro de Ciências Rurais (CCR), Universidade Federal de Santa Maria (UFSM), Santa Maria, RS, Brasil.

ABSTRACT: Bacteriophages have been investigated as alternative to the treatment of bacterial infections, including bovine mastitis, in production animals. In this meta-analysis, we evaluated in vitro efficiency of phages of Staphylococcus aureus against $S$. aureus, which is involved in the etiology of bovine mastitis. Seventeen studies were included and the bacterial lytic activity was extracted using proportion analysis. The lytic efficiency of phages was obtained in this meta-analysis using a random-effects model [significant difference $(P<0.05)]$. Forest plots were used to graphically represent the efficiency of phages on bacterial isolates. Most phages (e.g., CS1, DW2, SSA011, $\Phi S A 012$, ФSA022, ФSA023, ФSA024, ФSA025, ФSA037, ФSA038, ФSA039, ФSA041, ФSA042, ФSA043, ФSA044, MSA6, Ufv-aur2 to Ufv-aur11, SAH-1, SPW, vB SauM JS25, SaPh1 to SaPh6, SA, SANF, SA2, ФSA012, ФSA039, phi11, phiIPLA88, phiIPLA35, phiIPLA-RODI, phiIPLAC1C, SAJK-IND, vBSP-A1, vBSP-A2, STA1.ST29, EB1.ST11, EB1.ST27, Remus, and ISP) were efficiently lytics or infected most S. aureus isolates, demonstrating $80 \%(P<0.05)$ lytic efficiency. The phages $S A, S A N F$ and $S A 2$, also demonstrated lytic activity or infected the nonStaphylococcus aureus and Macrococcus caseolyticus isolates. In this meta-analysis, we compared and demonstrated the in vitro efficiency and host range of $S$. aureus phages. Additionally, the phages represent an alternative to be researched to treat bovine mastitis in dairy cattle caused by the prevalent microorganism, S. aureus.

Key words: bacteriophages, bovine mastitis, phages, Staphylococcus aureus.

Eficiência lítica in vitro de bacteriófagos de Staphylococcus aureus em bactérias de mastites bovina: uma meta-análise

RESUMO: Os bacteriófagos têm sido investigados como alternativa ao tratamento de infecções bacterianas em animais de produção, incluindo a mastite bovina. Nesta meta-análise, avaliamos a eficiencia in vitro de fagos de Staphylococcus aureus contra $S$. aureus envolvidas na etiologia da mastite bovina. Dezessete estudos foram incluídos e a atividade lítica bacteriana foi extraída usando análise de proporção. A eficiência lítica dos fagos foi obtida nesta meta-análise, usando um modelo de efeitos aleatórios (diferença significativa (P <0,05)). Os gráficos de Forest plots foram usados para representar graficamente a eficiência dos fagos em isolados bacterianos. Os fagos avaliados, na sua grande maioria, (por exemplo, CS1, DW2, ФSA011, ФSA012, ФSA022, ФSA023, ФSA024, ФSA025, ФSA037, ФSA038, ФSA039, ФSA041, ФSA042, ФSA043, ФSAfe U0f, ua04 SPW, vB_SauM_JS25, SaPh1 a SaPh6, SA, SANF, SA2, ФSA012, ФSA039, phi11, phiIPLA88, phiIPLA35, phiIPLA-RODI, phiIPLA-C1C, SAJK-IND, vBSP-A1, vBSP-A2, STA1.ST29, EB1.ST11, EB1.ST27, Remus, e ISP) foram eficientemente liticos ou infectaram a maioria dos isolados de S. aureus, demonstrando $80 \%(P<0,05)$ de eficiência litica. Os fagos SA, SANF e SA2 também demonstraram atividade litica ou infectaram os isolados Staphylococcus não-aureus e Macrococcus caseolyticus. Nesta meta-análise, comparamos e demonstramos a eficiencia in vitro e gama de hospedeiros de fagos de S. aureus. Adicionalmente, os fagos representam uma alternativa a ser pesquisada para o tratamento da mastite bovina em gado leiteiro causada pelo microrganismo prevalente, ou seja $S$. aureus. Palavras-chave: bacteriófagos, mastite bovina, fagos, Staphylococcus aureus.

\section{INTRODUCTION}

Bovine mastitis is defined as an inflammation of the mammary gland and the use of antimicrobials to treat of this disease in dairy cows has increased (GRAVE et al., 1999; MITCHELL et al., 1998; SHARMA; SINGH; BHADWAL, 2011). Among the etiological agents involved in the occurrence of mastitis of bacterial origin, S. aureus has been reported as the most prevalent microorganism 
globally (BARKEMA; et al., 2006; SOUZA,.et al., 2016; SEYOUM et al., 2017; SULEIMAN et al., 2018; MESQUITA, et al., 2019). Furthermore, an increase in penicillin resistance has been reported, as well as methicillin-resistant $S$. aureus (MRSA) in bovine milk (AQIB et al., 2017; SILVA et al., 2020). Once, the penicillin resistance is related to indiscriminate use of antibiotics with the absence of laboratory diagnosis and the antimicrobials sensitivity test to in the bovine mastitis, mainly caused by $S$. aureus (BEURON et al., 2014).

Therefore, bacterial resistance to available antimicrobials has increased, including in the veterinary field (PALMA et al., 2020). Thus, the discovery of alternatives to control bovine mammary gland infections is critical and therapeutic alternatives to treat bacterial infections, including the use of bacteriophages or phages, have been studied globally (BASDEW \& LAING, 2011;ROHDE et al., 2018).

Phages infect bacteria, causing cell lysis; consequently, they are considered potential therapeutic agents for more than a century (D’HERELLE, 1931). These viruses have received attention from many research groups (SULAKVELIDZE, 2004; MONK et al., 2010; SILLANKORVA \& AZEREDO, 2014), owing to their characteristics, including host specificity, lytic activity in pathogenic bacteria, absence of harm to humans and animals, and rapid application to combat the emergence of new bacterial threats (SULAKVELIDZE \& ZEMPHIRA; JR, 2001).

The mechanism of action of phages is completely different from those of antimicrobials and they are effective against multi-drug-resistant bacteria. Moreover, owing to their environmental presence, it is easier to find new phages than to develop new drugs or immunobiologicals (VEIGA-CRESPO; BARROS-VELÀZQUEZ; VILLA, 2010). Therefore, phage therapy is considered a promising alternative compared to the use of antimicrobials (PELFRENE et al., 2016), making this study remarkably relevant.

In vitro studies have investigated the use of phages in the biological control of bovine mastitis; however, variable results have been reported (SON et al., 2010; BASDEW \& LAING, 2011; IWANO et al., 2018). Therefore, these studies were selected for this meta-analysis, as well as standardized by the eligibility criteria to homogenize the samples. In addition, the studies with in vivo tests were not included because they did not meet the eligibility criteria. Thus, in this study, we performed a metaanalysis of in vitro efficiency of $S$. aureus phages against isolates $S$. aureus involved in bovine mammary-gland infections.

\section{MATERIALS AND METHODS}

\section{Search strategies}

A systematic review of the literature was performed, identifying studies that tested the lytic activity of phages of $S$. aureus isolates from bovine mastitis. The investigation was developed by pairs, focusing on studies that determine the host range of the phages. This review was conducted in the following four stages: identification, selection, eligibility assessment, and inclusion, according to the Preferred Reporting Items for Systematic Reviews and MetaAnalyses (PRISMA) guidelines (MOHER et al., 2009).

\section{Selection of studies}

Bibliographic research was performed using data from scientific journals indexed in the following databases: PubMed, Web of Science and ScienceDirect, using the search terms: phage OR phages OR bacteriophage OR bacteriophages AND mastitis NOT humans. Only publications in the English language were considered for this analysis (PURBA et al., 2020; Figure 1).

During the selection phase, duplicate publications were removed. Subsequently, the studies were evaluated based on the title and abstract. All studies related to tests using the lytic enzymes were excluded, as well as literature reviews.

The articles included in this meta-analysis were comprehensively assessed through the complete reading of the selected texts. The selected papers fulfilled the following eligibility criteria: $S$. aureus isolated from bovine mastitis, host-specific phages of $S$. aureus of bovine milk, determination of the range hosts, methodology that employed the use of a single phage, no association with other phages, and the performance of in vitro analyses. Additionally, the plaque assay, spot test and double-layered agar methods were included.

Notably, we excluded studies that reported the concomitant use of other molecules with antimicrobial potential, as well as those that included intracellular bacteria or other analyses that did not allow the visualization of lysis. These exclusions were necessary to ensure the homogeneity of samples to compare studies that were included in this meta-analysis.

The references cited in the articles were also analyzed and included in the present study based on the eligibility criteria described above. Thus, the information from the articles was systematized in a spreadsheet (Microsoft Excel ${ }^{\circledR}$ ). The bacterial lytic activity was extracted using proportion analysis. 


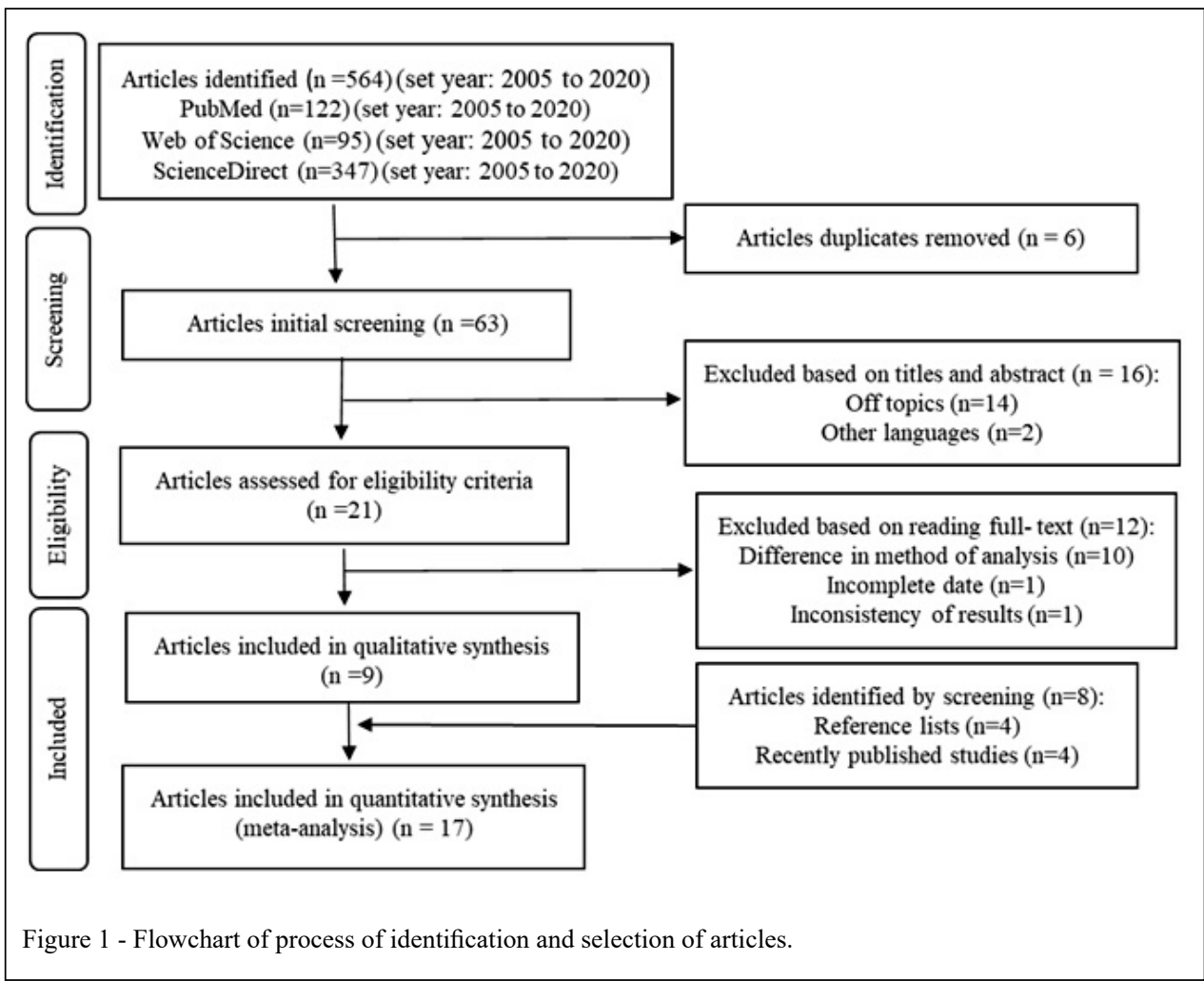

\section{Statistical analysis}

Initially, a logit transformation of the proportion data was performed based on the total number of bacterial isolates (total) versus the number of lysed bacterial isolates (events). Additionally, this procedure was used for each phage isolated and tested in each study. The lytic efficiency of $S$. aureus phages was obtained using random-effects model [significant difference $(\mathrm{P}<0.05)]$. Forest plots were used to graphically represent the meta-analysis result. In particular, the meta-analysis was conducted using the "Metaprop" package of R v3.4.2 software $^{\circledR}$.

\section{RESULTS}

\section{Selection of studies}

A total of 564 articles were found, including 122 studies from PubMed, 95 from Web of Science and 347 from ScienceDirect. Next, the articles were screened, and 21 were chosen and read completely, after which the eligibility criteria were evaluated. Consequently, nine articles met all eligibility criteria for this meta-analysis. The bibliographic references of the selected studies were reviewed and two other scientific publications were included. We performed a general search using the same indexers and other websites for studies that were not reviewed, as well as recently published studies to update the references. Thus, eight studies were included, resulting in a total of 17 articles that were analyzed in this current study (Figure 1). The period of publication of the selected articles ranged from June 2005 to September 2020. Information regarding the following aspects was obtained from each article: phage isolates, phage family, bacteria isolated from bovine milk, the presence of antimicrobial resistance or resistance genes, and techniques for analyzing the occurrence of bacterial lysis (Table 1 and Table 2).

\section{Occurrence of lytic activity and host range}

The total number of bacterial isolates analyzed in the studies was 603 , of which $92.37 \%$ (557/603) were $S$. aureus, which included $47.21 \%$ (263/557) of isolates that were resistant and $52.78 \%$ (294/557) of isolates that were non-resistant to antimicrobials. Based on the analysis of the Forest plots (Figure 2 and Figure 3), it was evident that the phages lysed the bacteria isolated from bovine milk samples. However, the lytic activity presented was variable in relation to the different phages and bacterial

Ciência Rural, v.51, n.10, 2021. 
Table 1 - Main characteristics of the 17 studies that were selected starting systematic review and included in the meta-analysis database.

\begin{tabular}{|c|c|c|c|c|c|c|c|}
\hline Author & Country & $\begin{array}{l}\text { Phages } \\
\text { family }\end{array}$ & $\begin{array}{l}\text { Phages } \\
\text { isolates }\end{array}$ & $\begin{array}{l}\text { Analysis } \\
\text { method }\end{array}$ & Bacterial isolated & $\mathrm{N}^{\mathrm{o}^{* *}}$ & $\begin{array}{l}\text { Antimicrobial } \\
\text { resistance }\end{array}$ \\
\hline $\begin{array}{l}\text { O'FLAHERTY } \\
\text { et al., (2005) }\end{array}$ & Ireland & Siphoviridae & $\begin{array}{c}\text { CS1 } \\
\text { DW2 }\end{array}$ & Spot test & S. aureus & 3 & N/A \\
\hline $\begin{array}{l}\text { SYNNOTT et } \\
\text { al., (2009) }\end{array}$ & Japan & Myoviridae & $\begin{array}{c}\text { ФSA003 } \\
\text { ФSA004 } \\
\text { ФSA011 } \\
\text { ФSA012 } \\
\text { ФSA022 to } \\
\text { ФSA026 } \\
\text { ФSA037 to } \\
\text { ФSA039 } \\
\text { ФSA041 to } \\
\text { ФSA044 }\end{array}$ & $\begin{array}{l}\text { Double- } \\
\text { layered } \\
\text { agar }\end{array}$ & S. aureus & 16 & N/A \\
\hline $\begin{array}{l}\text { GARCÍA et al., } \\
(2009)\end{array}$ & Spain & N/A & $\begin{array}{c}\text { ФА72 ФН5 ФL7 } \\
\text { ФL13 ФA8 } \\
\text { ФG7 }\end{array}$ & $\begin{array}{l}\text { Double- } \\
\text { layered } \\
\text { agar }\end{array}$ & S. aureus & 14 & N/A \\
\hline $\begin{array}{l}\text { SON et al., } \\
(2010)\end{array}$ & Korea & Myoviridae & $\begin{array}{l}\text { SAP-1 } \\
\text { SAP-3 }\end{array}$ & $\begin{array}{l}\text { Double- } \\
\text { layered } \\
\text { agar }\end{array}$ & $\begin{array}{c}\text { S. aureus; } S . \\
\text { epidermidis; } S . \\
\text { agalactie; } S . \text { uberis; } \\
\text { E. faecalis; } E . \text { coli; } L \text {. } \\
\text { plantarum; C. koseri; } \\
\text { S. haemolyticus }\end{array}$ & 20 & $\begin{array}{l}\text { Nal, Str, Gen, } \\
\text { Ami, Ct, Cfl, } \\
\text { Nor, Eri, Oxa }\end{array}$ \\
\hline $\begin{array}{l}\text { KWIATEK et } \\
\text { al., (2012) }\end{array}$ & Poland & Myoviridae & MSA6 & $\begin{array}{l}\text { Double- } \\
\text { layered } \\
\text { agar }\end{array}$ & $\begin{array}{c}\text { S. aureus; } S \\
\text { epidermidis; } S \text {. } \\
\text { saprophyticus }\end{array}$ & 35 & MRSA, VRSA \\
\hline $\begin{array}{l}\text { DIAS et al., } \\
(2013)\end{array}$ & Brazil & Myoviridae & $\begin{array}{l}\text { Ufv-aur2 to } \\
\text { Ufv-aur11 }\end{array}$ & $\begin{array}{c}\text { Double- } \\
\text { layered } \\
\text { agar }\end{array}$ & S. aureus & 20 & $\begin{array}{c}\text { Amp, Gen, Pen, } \\
\text { Tet, Eri, Rif, } \\
\text { Ami, Clo, Cro, } \\
\text { Oxa, Cfl, Cli, } \\
\text { Cip, Van, Sut }\end{array}$ \\
\hline $\begin{array}{l}\text { HAN et al. } \\
(2013)\end{array}$ & Korea & Myoviridae & SAH-1 & $\begin{array}{l}\text { Double- } \\
\text { layered } \\
\text { agar }\end{array}$ & S. aureus; E. faecalis & 47 & MRSA \\
\hline $\begin{array}{l}\text { LI \& ZHANG } \\
(2014)\end{array}$ & China & Myoviridae & SPW & Spot test & S. aureus; E. coli & 05 & MRSA \\
\hline
\end{tabular}

MRSA: methicillin-resistant $S$. aureus. VRSA: vancomycin-resistant $S$. aureus. Nal: nalidixic acid. Str: streptomycin. Ct: colistin. Gen: gentamycin. Ami: amicacin. Cfl: cephalothin. Nor: norfloxacin. Eri: erythromycin. Oxa: oxacillin. Amp: ampicillin. Cfo: cefoxitin. Van: vancomycin. Dc: dicloxacillin. Pef: pefloxacin. Cxm: cefuroxime. Ctx: cefotaxime. Sxt: sulfamethoxazole-trimethoprim. Caz: ceftazidime. Met: methicillin. Pen: penicillin. Pen G: penicilina G. A/F: amoxycillin/ fucloxacillin. Ob: oxytetracycline. Tr: trimethopim. Tet: tetracycline. Rif: rifampicin. Clo: chloramphenicol. Cli: clindamycin. Cip: ciprofloxacin. Sut: sulfazotrim. ${ }^{* *}$ Number of isolates bacterial from each study. N/A: Not available.

isolates tested. Therefore, most $S$. aureus phages (e.g. CS1, DW2, ФSA011, ФSA012, ФSA022, ФSA023, ФSA024, ФSA025, ФSA037, ФSA038, ФSA039, ФSA041, ФSA042, ФSA043, ФSA044, MSA6, Ufvaur2 to Ufv-aur11, SAH-1, SPW, vB_SauM_JS25, SaPh1 to SaPh6, SA, SANF, SA2, ФSA012, ФSA039, phi11, phiIPLA88, phiIPLA35, phiIPLA-RODI, phiIPLA-C1C, SAJK-IND, vBSP-A1, vBSP-A2, STA1.ST29, EB1.ST11, EB1.ST27, Remus, and ISP) were efficiently lytics or infected most of $S$. aureus isolates tested, except phages ФA72, ФH5, ФL7, ФL13, ФA8, ФG7, ФSA003, ФSA004, ФSA026,
SAP-1, SAP-3, MSP, Romulus, and DSM105264, which presented low lytic efficiency or infected a low number of $S$. aureus isolates. The phages demonstrated $80 \%(\mathrm{P}<0.05)$ lytic efficiency against $S$. aureus isolates (Figure 2). Additionally, the lytic activity of phages is species-specific, that is, these viruses are only able to destroy their bacterial host. Conversely, the phages SANF, SA2 and SA also demonstrated lytic activity for isolates of non-S. aureus bacteria (e.g. Staphylococcus chromogenes, Staphylococcus saprophyticus, Staphylococcus xylosus, Staphylococcus sciuri, and Staphylococcus 
Table 2 - Main characteristics of the 17 studies that were selected starting systematic review and included in the meta-analysis database (continued).

\begin{tabular}{|c|c|c|c|c|c|c|c|}
\hline Author & Country & $\begin{array}{l}\text { Phages } \\
\text { family }\end{array}$ & $\begin{array}{l}\text { Phages } \\
\text { isolates }\end{array}$ & $\begin{array}{l}\text { Analysis } \\
\text { method }\end{array}$ & Bacterial isolated & $\mathrm{N}^{\mathrm{N}^{* *}}$ & $\begin{array}{l}\text { Antimicrobial } \\
\text { resistance }\end{array}$ \\
\hline $\begin{array}{l}\text { ZHANG et al. } \\
(2014)\end{array}$ & China & Myoviridae & vB_SauM_JS25 & Spot test & S. aureus & 52 & N/A \\
\hline $\begin{array}{l}\text { BASDEW \& } \\
\text { LAING (2015) }\end{array}$ & $\begin{array}{l}\text { South } \\
\text { Africa }\end{array}$ & Myovoridae & $\mathrm{SaPh} 1$ to $\mathrm{SaPh} 6$ & Spot test & S. aureus & 4 & $\begin{array}{c}\text { Amp, Pen G, Met, } \\
\text { A/F, Eri, Str, Tet, } \\
\text { Ob, Van, Tr }\end{array}$ \\
\hline $\begin{array}{l}\text { TAHIR et al. } \\
(2017)\end{array}$ & Pakistan & N/A & $\begin{array}{c}\text { SA } \\
\text { SANF } \\
\text { SA2 }\end{array}$ & Spot test & $\begin{array}{c}\text { S. aureus; } S . \\
\text { xylosus; } M . \\
\text { caseolyticus; } S . \\
\text { saprophyticus; } S \text {. } \\
\text { succinus; } S . \text { sciuri }\end{array}$ & 11 & N/A \\
\hline $\begin{array}{l}\text { IWANO et al. } \\
(2018)\end{array}$ & Japan & Myoviridae & ФSA012 ФSA039 & Spot test & S. aureus & 93 & N/A \\
\hline $\begin{array}{l}\text { VARELA-ORTIZ } \\
\text { et al. (2018) }\end{array}$ & México & $\begin{array}{c}\text { Siphovirida } \\
e \\
\text { Myoviridae }\end{array}$ & $\begin{array}{c}\text { phi11 phiIPLA88 } \\
\text { phiIPLA35 } \\
\text { phiIPLA-RODI } \\
\text { phiIPLA-C1C }\end{array}$ & Spot test & S. aureus & 27 & $\begin{array}{l}\text { Pen, Dc, Amp, Tet, } \\
\text { Ctx, Cfl, Pef, Gen, } \\
\text { Eri, Stx, Caz, Cxm }\end{array}$ \\
\hline $\begin{array}{l}\text { GANAIE et al. } \\
(2018)\end{array}$ & India & $\begin{array}{l}\text { Myoviridae } \\
\text { Podoviridae }\end{array}$ & $\begin{array}{l}\text { SAJK-IND } \\
\text { MSP }\end{array}$ & Spot test & $\begin{array}{l}\text { S. aureus; E. coli; } \\
\text { S. agalactie; } K \text {. } \\
\text { pneumonie; } P \text {. } \\
\text { aureuginosa }\end{array}$ & 125 & MRSA \\
\hline $\begin{array}{l}\text { GENG et al. } \\
(2019)\end{array}$ & China & $\begin{array}{l}\text { Myoviridae } \\
\text { Podoviridae }\end{array}$ & $\begin{array}{c}\text { vBSM-A1 vBSP- } \\
\text { A2 }\end{array}$ & $\begin{array}{l}\text { Double- } \\
\text { layered } \\
\text { agar }\end{array}$ & $\begin{array}{c}S . \text { aureus; } S . \\
\text { chromogens; } K \text {. } \\
\text { pneumoniae; } S \text {. } \\
\text { parasanguinis } \\
\text { A. pyogenes; } S . \\
\text { agalactie; } E \text {. coli }\end{array}$ & 29 & N/A \\
\hline $\begin{array}{l}\text { TITZE et al. } \\
(2020)\end{array}$ & Germany & $\begin{array}{l}\text { Myoviridae } \\
\text { Podoviridae }\end{array}$ & $\begin{array}{l}\text { STA1.ST29 } \\
\text { EB1.ST11 } \\
\text { EB1.ST27 }\end{array}$ & Spot test & S. aureus & 92 & N/A \\
\hline $\begin{array}{l}\text { NGASSAM- } \\
\text { TCHAMBA et } \\
\text { al. }(2020)\end{array}$ & Belgium & N/A & $\begin{array}{c}\text { Romulus } \\
\text { Remus } \\
\text { ISP } \\
\text { DSM105264 }\end{array}$ & Spot test & S. aureus & 10 & $\begin{array}{l}\text { Cfo, Amp, Tet, } \\
\text { Amo, Cip, Cli, Ct, } \\
\text { Eri, Ff, Gen, Lzd, } \\
\text { Pen, Tr, Sulfatrim, } \\
\text { Sulfamycin, }\end{array}$ \\
\hline
\end{tabular}

MRSA: methicillin-resistant $S$. aureus. VRSA: vancomycin-resistant $S$. aureus. Nal: nalidixic acid. Str: streptomycin. Ct: colistin. Gen: gentamycin. Ami: amicacin. Cfl: cephalothin. Nor: norfloxacin. Eri: erythromycin. Oxa: oxacillin. Amp: ampicillin. Cfo: cefoxitin. Van: vancomycin. Dc: dicloxacillin. Pef: pefloxacin. Cxm: cefuroxime. Ctx: cefotaxime. Sxt: sulfamethoxazole-trimethoprim. Caz: ceftazidime. Met: methicillin. Pen: penicillin. Pen G: penicilina G. A/F: amoxycillin/ fucloxacillin. Ob: oxytetracycline. Tr: trimethopim. Tet: tetracycline. Rif: rifampicin. Clo: chloramphenicol. Cli: clindamycin. Cip: ciprofloxacin. Sut: sulfazotrim. Ff: Florfenicol. Lzd: Lizenoid. ${ }^{* *}$ Number of isolates bacterial from each study. N/A: Not available.

succinus) and other species (e.g. Macrococcus caseolyticus) (Figure 3). Therefore, the lytic efficiency was $30 \%$ for non-S. aureus bacteria and $16 \%$ for other bacterial species (e.g. Streptococcus agalactiae, Streptococcus uberis, Streptococcus parasanguinis, Arcanobacterium pyogenes, Kocuria rosea, Enterococcus faecalis, Escherichia coli, Klebsiella pneumoniae, Pseudomonas aeruginosa, Lactobacillus plantarum, Citrobacter koseri, and Macrococcus caseolyticus) $(\mathrm{P}<0.05)$ (Figure 3).

\section{DISCUSSION}

Data analysis and review revealed that most phages of $S$. aureus, specifically in the family Myoviridae, presented prominent and specific activity against 603 bacterial isolates from bovine mastitis. These findings demonstrate that these phages may be studied for the development of therapeutic alternatives for bovine mastitis and could be used to target infections involving $S$. aureus. 


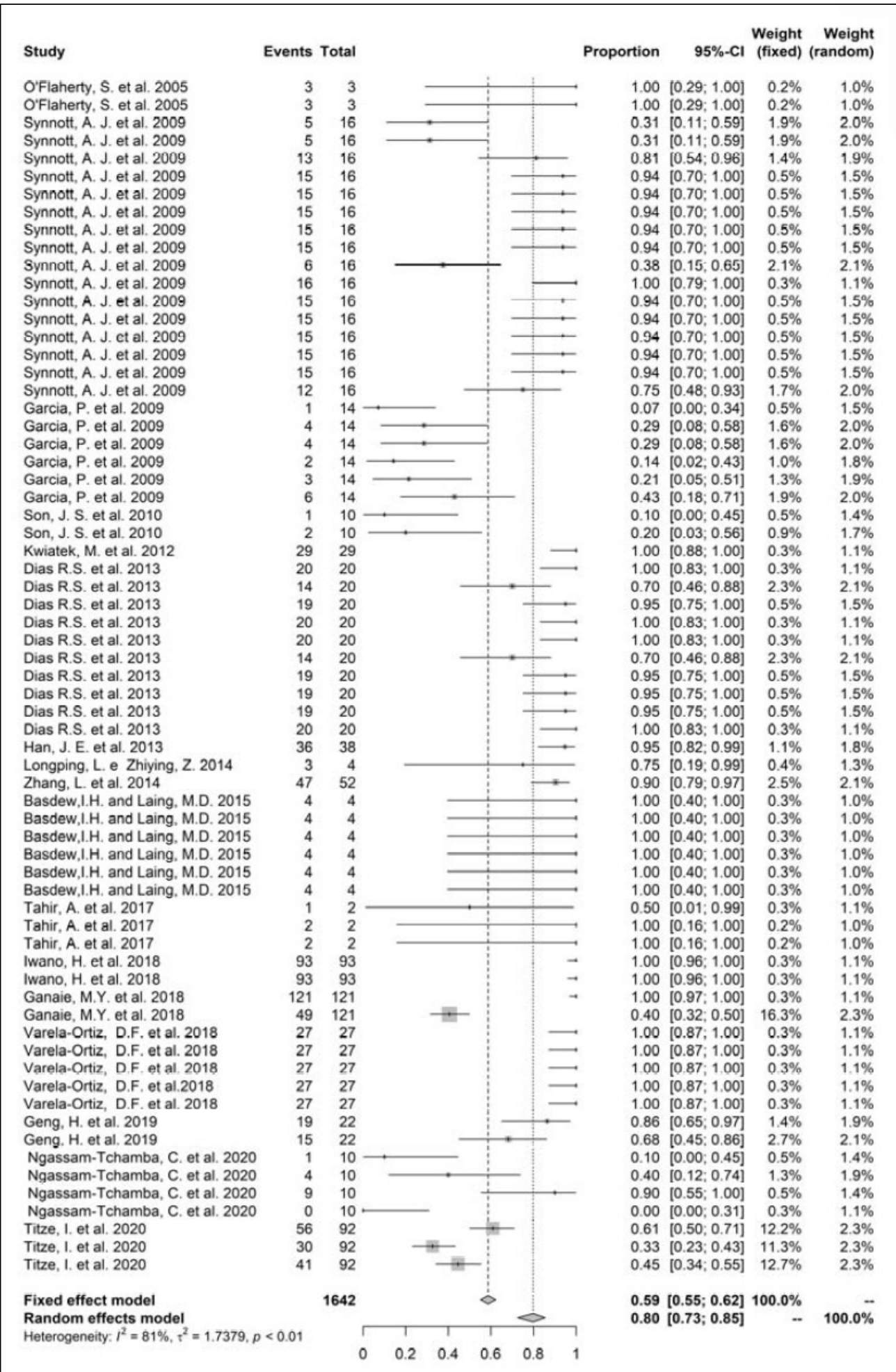

Figure 2 - Forest plots of efficiency from Staphylococcus aureus phages in bacterial isolates Staphylococcus aureus.

Total: number of bacterial isolates from bovine mastitis. Events: number of bacterial isolates demonstrated lytic efficiency (i.e. proportion analysis). Analysis through random-effects model $(\mathrm{P}<0.05)$.

Ciência Rural, v.51, n.10, 2021. 
Additionally, the efficiency of the phages against several bacterial isolates permitted us to verify their probable infectivity and lethality in bacterial isolates responsible for bovine mastitis, but principally those against $S$. aureus. As shown in Figure 2 , the lytic efficiency against $S$. aureus isolates was $80 \%$. The results of this meta-analysis also verified the possibility of using the analyzed phages to infect other bacterial species involved in bovine mastitis.

It was observed that phages SA, SA2 and SANF demonstrated lytic activity against $S$. saprophyticus, S. xylosus, S. sciuri, S. succinus, and $M$. caseolyticus. Although the main characteristic of phages is their host specificity, some phages can infect different bacterial genera and species (BOHANNAN \& LENSKI, 1997). Consequently, these phages should be tested in more isolates to confirm their possible host amplitude. Once, if there is no resistance displayed by a specific bacterium, the phage does not need to find another host cell to infect, but if resistance is exhibited, the phage seeks diversification of the species host to continue its infectious cycle

The high efficiency of cell lysis by phages is based on the specificity of bacterial receptors and cell disintegration after a short viral life cycle, leading to the rapid elimination of the target cell (LECLERC et al., 2000; MATSUZAKI et al., 2005). In grampositive bacteria, such as $S$. aureus, the receptors are located in the peptidoglycans (or mureins) and teichoic acids in the bacterial cell wall ( SHAW \& CHATTERJEE, 1971; KANEKO et al., 2009; XIA et al., 2011). Phages are bound to these compounds present in the cell wall to be adsorbed into the cell.

In this study, some phages (SA, SANF and SA2) were lytic in other Staphylococcus species and

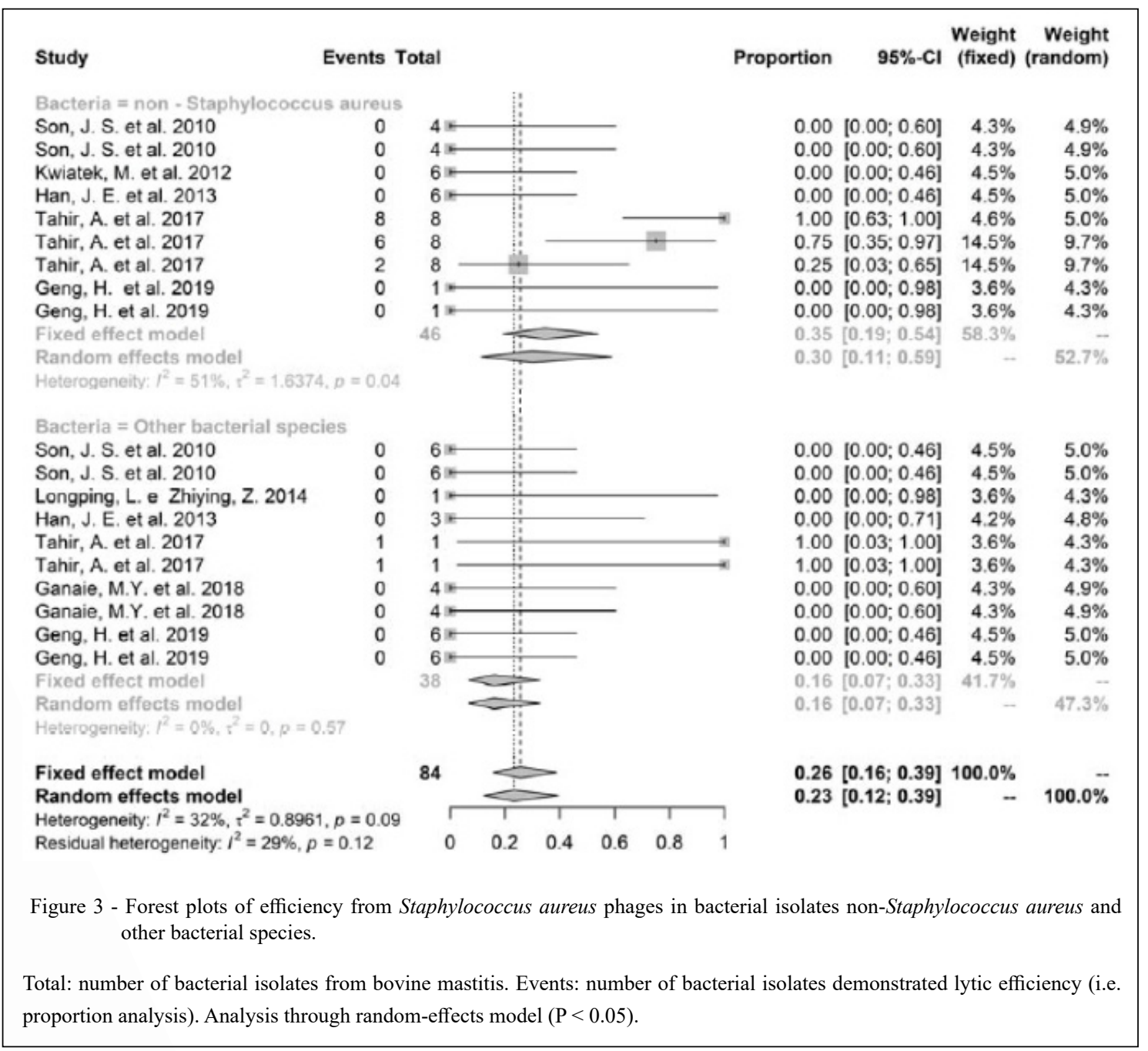

Ciência Rural, v.51, n.10, 2021. 
Macrococcos caseolyticus. Importantly, the genus Macrococcos belongs to the same family as $S$. aureus and is also a Gram-positive bacterium. This suggests that these microorganisms share similar receptors for the phages.

The methodology used allowed greater precision in establishing the effects of the treatments, regulating data heterogeneity, and facilitating the verification of a greater number of results (LOVATTO et al., 2007). In vitro lytic activity tests of studies presented variability; thus, the eligibility criteria conferred the best homogeneity of samples, allowing comparisons and analyses of data.

Phage SA (HAMZA et al., 2016) was excluded from this meta-analysis because of a contradiction in the results of the phage lytic activity against $K$. pneumoniae isolates. In addition, studies using bacterial isolates from humans and other animals were also excluded, since the aim of the present study was to focus on phages used for the prevention and treatment of bovine mastitis.

Notably, there is a scarcity of studies evaluating in vivo lytic activity of $S$. aureus phages in cows (LERONDELLE \& POUTREL, 1980; GILL et al., 2006a) and mice (ALDOORI et al., 2015; BREYNE et al., 2017; IWANO et al.et al., 2018; GENG et al., 2019). However, we opted to exclude these studies to homogenize the data for this meta-analysis.

Phage therapy against mastitis presents many important challenges. Some of the problems encountered are phage stability, inhibitory effects on the cow's immune system and certain thermolabile proteins are present in raw milk that affect phage-cell interaction (O'FLAHERTY et al., 2005; GILL et al., 2006b; TANJI et al., 2015; BARI et al., 2017).

Another issue is the possibility of bacteria developing phage resistance. However, the use of a cocktail containing multiple phages could be indicated to circumvent this phenomenon, since the bacterium must develop simultaneous resistance mechanisms against multiple phages. This phenomenon is less likely to occur when compared to a single phage used to lysis a particular bacterium (OECHSLIN, 2018). A limitation for the use of phages for mastitis therapy would be the need to perform laboratory diagnosis and testing the susceptibility of the agent to phages. However, this fact is also a current limitation for antimicrobial use.

The increase in multi-resistant bacteria, including $S$. aureus, the principal microorganism involved in the etiology of bovine mastitis, has necessitated the search for alternative treatments for this disease (FERNÁNDEZ et al., 2018). Thus, the use of phages may be recommended in cases where mastitis is caused by antimicrobial-resistant bacteria (SULAKVELIDZE; ZEMPHIRA; JR, 2001), since phages infect and eliminate bacteria through mechanisms distinct from those of antimicrobials (MONK et al., 2010).

\section{CONCLUSION}

This meta-analysis describes the in vitro infectivity of $S$. aureus phages against bacterial cells, demonstrating the lytic potential of these viruses. Thus, this study evaluates the efficiency of $S$. aureus phages in the control of bovine mastitis owing to their lytic activity, particularly against $S$. aureus isolates, including MRSA.

In addition, we suggest that among the evaluated phages, those with high lytic efficiency could be selected to produce a cocktail to be tested in vivo for the treatment and/or prevention of mastitis caused by $S$. aureus. Other investigations using phages as an alternative treatment method, should be performed to ensure the health of the dairy cattle using environmentally sustainable technologies, thereby preserving the efficacy of antimicrobials.

\section{ACKNOWLEDGMENTS}

The authors acknowledge the support provided by the Brazilian agencies: Coordenação de Aperfeiçoamento de Pessoal de Nível Superior (CAPES) (financial code 001) and Conselho Nacional de Desenvolvimento Científico e Tecnológico (CNPq).

\section{DECLARTION OF CONFLICT OF INTEREST}

The authors declare no conflict of interest. The founding sponsors had no role in the design of the study; in the collection, analyses, or interpretation of data; in the writing of the manuscript, and in the decision to publish the results.

\section{AUTHORS' CONTRIBUTIONS}

All authors contributed equally for the conception and writing of the manuscript. All authors critically revised the manuscript and approved of the final version.

\section{REFERENCES}

ALDOORI, A. et al. Bacteriophage biocontrol rescues mice bacteremic of vlinically isolated mastitis from dairy cows associated with methicillin-resistant Staphyloccocus aureus. Advences in Microbiology, v.5, p.383-403, 2015. Available from: $<$ https://doi.org/10.4236/aim.2015.56040>. Accessed: Apr. 20, 2018. doi: 10.4236/aim.2015.56040.

AQIB, A. I. et al. Antibiotic susceptibilities and prevalence of Methicillin Resistant Staphylococcus aureus (MRSA) 
isolated from bovine milk in Pakistan. Acta Tropica, v.176, p.168-172, 2017. Available from: <https://doi.org/10.1016/j. actatropica.2017.08.008>. Accessed: Apr. 18, 2018. doi: 10.1016/j. actatropica.2017.08.008

BARKEMA, H. W.; et al., Invited Review: The role of cow, pathogen, and treatment regimen in the therapeutic success of bovine Staphylococcus aureus mastitis. Journal Dairy Science, v.89, n.6, p.1877-95, 2006. Available from: <https://10.3168/jds. S0022-0302(06)72256-1>. Accessed: Nov. 06, 2020. doi: 10.3168/ jds.S0022-0302(06)72256-1.

BARI, S. M. N. et al. Strategies for editing virulent Staphylococcal phages using CRISPR-Cas10. ACS Synth Biol, v.37, n.4, p.784-790, 2017. Available from: $<$ https://doi. org/10.1183/09031936.00063810>. Accessed: Apr. 20, 2018. doi: 10.1183/09031936.00063810.

BASDEW, I. H.; LAING, M. D. Mini-Review : Biological control of bovine mastitis using bacteriophage therapy. Science against microbial pathogens: communicating current research and technological advances, p. 386-393, 2011. Accessed: Apr. 20, 2018.

BEURON, D. C. et al. Risk factors associated with the antimicrobial resistance of Staphylococcus aureus isolated from bovine mastitis. Pesquisa Veterinária Brasileira, v.34, n.10, p.947-952, 2014. Available from: <https://doi.org/10.1590/S0100736X2014001000004>. Accessed: Jan. 05, 2021. doi: 10.1590/ S0100-736X2014001000004.

BOHANNAN, B. J. M.; LENSKI, R. E. Effect of resource enrichment on a chemostat community of bacteria and bacteriophage. Ecology, v.78, n.8, p.2303-2315, 1997. Accessed: May, 02, 2018

BREYNE, K. et al. Efficacy and safety of a bovine-associated Staphylococcus aureus Phage Cocktail in a murine model of mastitis. Frontiers in Microbiology, v.8, p.1-11, 2017. Available from: <https://doi.org/10.3389/fmicb.2017.02348>. Accessed May, 02, 2018. doi: 10.3389/fmicb.2017.02348.

D'HERELLE, F. Bacteriophage as a treatment in acute medical and surgical infections. ew York Academy of Medicine, v.7, n.5, p.329-348, 1931. Available from: <https://www.researchgate.net/ publication/339422375_Bacteriophages_for_Chronic_Wound Treatment From Traditional to Novel Delivery Systems $>$. Accessed: Jan. 10, 2021.

FERNÁNDEZ, L. et al. Application of bacteriophages in the agrofood sector: a long way toward approval. Frontiers in Cellular and Infection Microbiology, v.8, n.8, p.1-5, 2018. Available from: <https://doi.org/10.3389/fcimb.2018.00296>. Accessed May, 02, 2018. doi: 10.3389/fcimb.2018.00296.

GENG, H. et al. Evaluation of phage therapy in the treatment of Staphylococcus aureus-induced mastitis in mice. Folia Microbiologica, 2019. Available from: <https://doi.org/10.1007/ s12223-019-00729-9>. Accessed: May, 02, 2018. doi: 0.1007/ s12223-019-00729-9.

GILL, J. J. et al. Efficacy and pharmacokinetics of bacteriophage therapy in treatment of subclinical Staphylococcus aureus mastitis in lactating dairy cattle. Antimicrobial Agents and Chemotherapy, v.50, n.9, p.2912-2918, 2006 a. Available from: $<$ https://doi.org/10.1128/AAC.01630-05>. Accessed: Apr. 26, 2018. doi: 10.1128/AAC.01630-05.
GILL, J. J. et al. Bovine whey proteins inhibit the interaction of Staphylococcus aureus and bacteriophage K. Journal of Applied Microbiology, v.101, n.2, p.377-386, 2006 b. Available from: $<$ https://doi.org/10.1111/j.1365-2672.2006.02918.x>. Accessed: Apr. 27, 2018. doi: 10.1111/j.1365-2672.2006.02918.x.

GRAVE, K. et al. The usage of veterinary antibacterial drugs for mastitis in cattle in Norway and Sweden during 19901997. Preventive Veterinary Medicine, v. 42, n.1, p.45-55, 1999. Available from: <https://doi.org/10.1016/S01675877(99)00057-4>. Accessed: Apr. 28, 2018. doi: 10.1016/S01675877(99)00057-4

HAMZA, A. et al. The Lytic SA phage demonstrate bactericidal activity against mastitis causing Staphylococcus aureus. Open Life Sciences, v.11, n.1, p.39-45, 2016. Available from: $<$ https:// doi.org/10.1515/biol-2016-0005>. Accessed: May, 02, 2018. doi: 10.1515/biol-2016-0005.

HOLMFELDT, K. et al. Large variabilities in host strain susceptibility and phage host range govern interactions between lytic marine phages and their Flavobacterium hosts. Applied and Environmental Microbiology, v.73, n.21, p.6730-6739, 2007. Available from: <https://doi.org/10.1128/AEM.0139907>. Accessed: Apr. 28, 2018. doi: 10.1128/AEM.01399-07.

IWANO, H. et al. Bacteriophage $\Phi$ SA012 has a broad host range against Staphylococcus aureus and effective lytic vapacity in a mouse mastitis model. Biology, v.7, n.1, p.8, 2018. Available from: $<$ https://doi.org/10.3390/biology7010008>. Accessed: Apr. 18, 2018. doi: $10.3390 /$ biology 7010008 .

KANEKO, J. et al. Identification of ORF636 in phage $\varphi$ SLT carrying panton-valentine leukocidin genes, acting as an adhesion protein for a poly (glycerophosphate) chain of lipoteichoic acid on the cell surface of Staphylococcus aureus. Journal of Bacteriology, v.191, n.14, p.4674-4680, 2009. Available from: $<$ https://doi.org/10.1128/JB.01793-08>. Accessed: Apr. 28, 2018. doi: 10.1128/JB.01793-08.

LECLERC, H. et al. Bacteriophages as indicators of enteric viruses and public health risk in groundwaters. Journal of Applied Microbiology, v.88, n.1, p.5-21, 2000. Available from: $<$ https://doi.org/10.1046/j.1365-2672.2000.00949.x>. Accessed: Apr. 28, 2018. doi: 10.1046/j.1365-2672.2000.00949.x.

LERONDELLE, C. \& POUTREL, B. Bacteriophage treatment trials for lactating staphylococcal breast infection. Annales Recherches Veterinaires, v.11, n.4, p.421-426, 1980.

LOVATTO, P. A. et al. Meta-analysis in scientific research: focus on methodologies. Revista Brasileira de Zootecnia, v.36, n.suppl, p.285-294, 2007. Available from: <https://doi.org/10.1590/S151635982007001000026>. Accessed: Apr. 15, 2018. doi: 10.1590/ S1516-35982007001000026.

MATSUZAKI, S. et al. Bacteriophage therapy: A revitalized therapy against bacterial infectious diseases. Journal of Infection and Chemotherapy, v.11, n.5, p.211-219, 2005. Available from: $<$ https://doi.org/10.1007/s10156-005-0408-9>. Accessed: May, 03, 2018. doi: $10.1007 / \mathrm{s} 10156-005-0408-9$.

MESQUITA, A. A. et al. Staphylococcus aureus and Streptococcus agalactiae: prevalence, resistance to antimicrobials, and their relationship with the milk quality of dairy cattle herds in Minas Gerais state, Brazil. Pesquisa Veterinária Brasileira, v.39, n.5, 
p.308-316, 2019. Available from: <https://doi.org/10.1590/16785150-PVB-5821>. Accessed: Nov. 06, 2020. doi: 10.1590/16785150-PVB-5821.

MITCHELL, J. M. et al. Antimicrobial drug residues in milk and meat: causes, concerns, prevalence, regulations, tests, and test performance. Journal of Food Protection, v.61, n.6, p.742-756, 1998. Available from: <https://doi.org/10.4315/0362028X-61.6.742>. Accessed: Apr. 28, 2018. doi: 10.4315/0362028X-61.6.742.

MOHER, D. et al. Preferred reporting items for systematic reviews and meta-analyses: The PRISMA statement. PLoS Medicine, v.6, n.7, 2009. Available from: <https://doi.org/10.1371/journal. pmed.1000097>. Accessed: Apr. 28, 2018. doi: 10.1371/journal. pmed.1000097.

MONK, A. B. et al. Bacteriophage applications: Where are we now? Letters in Applied Microbiology, v.51, n.4, p.363-369, 2010. Available from: <https://doi.org/10.1111/ j.1472-765X.2010.02916.x>. Accessed: Apr. 30, 2018. doi: 10.1111/j.1472-765X.2010.02916.x.

NGASSAM-TCHAMBA, C. et al. In vitro and in vivo assessment of phage therapy against Staphylococcus aureus causing bovine mastitis. Journal of Global Antimicrobial Resistance, v.22, p.762-770, 2020. Available from: <https:// doi.org/10.1016/j. jgar.2020.06.020>. Accessed: Nov. 06, 2020. doi: 10.1016/j. jgar.2020.06.020.

O'FLAHERTY, S. et al. Isolation and characterization of two anti-staphylococcal bacteriophages specific for pathogenic Staphylococcus aureus associated with bovine infections. Letters in Applied Microbiology, v.41, n.6, p.482-486, 2005. Available from: <https://doi.org/10.1111/j.1472765X.2005.01781.x>. Accessed: Jun. 06, 2018. doi: 10.1111/j.1472-765X.2005.01781.x.

OECHSLIN, F. Resistance development to bacteriophages occurring during bacteriophage therapy. Viruses, v.10, n.7, 2018. Available from: <https://doi.org/10.3390/v10070351>. Accessed: Jun. 06, 2018. doi: 10.3390/v10070351.

PALMA, E. et al. Antimicrobial resistance in veterinary medicine: An Overview. International Journal of Molecular Sciences, v.21, n.1914, 2020. Available from: <https:// doi.org/10.3390/ ijms21061914>. Accessed: Nov. 06, 2020. doi: 10.3390/ ijms21061914.

PELFRENE, E. et al. Bacteriophage therapy: A regulatory perspective. Journal of Antimicrobial Chemotherapy, v.71, n.8, p.2071-2074, 2016. Available from: <https://doi org/10.1093/jac/dkw083>. Accessed: Jun. 06, 2018. doi: 10.1093/ $\mathrm{jac} / \mathrm{dkw} 083$.

PURBA, R. A. P.; et al. The links between supplementary tannin levels and conjugated linoleic acid (CLA) formation in ruminants: A systematic review and meta-analysis, Plos One, v.15, n.3, 2020. Available from: <https://doi.org/10.1371/journal.pone.0216187>. Accessed: Jan. 10, 2021. doi: 10.1371/journal.pone.0216187.

RODRIGUEZ-VALERA, F. et al. Explaining microbial population genomics through phage predation. Nature Reviews Microbiology, v.7, n.11, p.828-836, 2009. Available from: $<$ https://doi.org/10.1038/nrmicro2235>. Accessed: Apr.18, 2018. doi: $10.1038 /$ nrmicro2235.
ROHDE, C.; et al. Bacteriophages: A Therapy Concept against Multi-Drug-Resistant Bacteria. Surgical Infections, v.19, n.8, 2018. Available from: <https://doi.org/ 10.1089/sur.2018.184>. Accessed: Jan. 04, 2021. doi: 10.1089/sur.2018.184.

SEYOUM, B. et al. Prevalence, risk factors and antimicrobial susceptibility test of Staphylococcus aureus in Bovine cross breed mastitic milk in and around Asella town, Oromia regional state, southern Ethiopia. Acta Tropica, v.177, n.September, p.32-36, 2017. Available from: <https://doi.org/10.1016/j. actatropica.2017.09.012>. Accessed: Apr. 18, 2018. doi: 10.1016/j. actatropica.2017.09.012.

SHARMA, N.; SINGH, N. K.; BHADWAL, M. S. Relationship of somatic cell count and mastitis: An overview. Asian-Australasian Journal of Animal Sciences, v.24, n.3, p.429-438, 2011. Available from: <https://doi.org/10.5713/ajas.2011.10233>. Accessed: Apr. 28, 2018. doi: 10.5713/ajas.2011.10233.

SHAW, D. R.; CHATTERJEE, A. N. O-Acetyl groups as a component of the bacteriophage receptor on Staphylococcus aureus cell walls. Journal of Bacteriology, v.108, n.1, p.584$585,1971$.

SILLANKORVA, S.; AZEREDO, J. Chapter 20 - Bacteriophage attack as an anti- biofilm strategy. In: Bacteriophage as Anti-biofi Im Strategy. v.1147, p.105-126, 2014. E-book. Available from: $<$ https://doi.org/10.1007/978-1-4939-0467-9>. Accessed: Apr. 22, 2018. doi: 10.1007/978-1-4939-0467-9.

SILVA, A. T. F. et al. Occurrence of $\beta$-lactam-resistant Staphylococcus aureus in milk from primiparous dairy cows in the northeastern region of Brazil. Tropical Animal Health and Production, v.52, p.2303-2307, 2020. Available from: <https:// doi.org/10.1007/s11250-020-02259-w>. Accessed: Nov. 06, 2020. doi: $10.1007 / \mathrm{s} 11250-020-02259-w$.

SOUZA, F. N. et al. Somatic cell count and mastitis pathogen detection in composite and single or duplicate quarter milk samples. Pesquisa Veterinária Brasileira, v.36, n.9, p.811-818. 2016. Available from: <https://10.1590/S0100736X2016000900004>. Accessed: Nov. 06, 2020. doi: 10.1590/ S0100-736X2016000900004.

SULAKVELIDZE, A. Bacteriophages-Biology and Application. : CRC Press, Boca Raton, 2004. E-book.

SULAKVELIDZE, A.; ZEMPHIRA, A.; JR, G. M. Bacteriophage therapy. Antimicrobial Agents and Chemotherapy, v.45, n.3, p.649-659, 2001. Available from: <https://doi.org/10.1128/ AAC.45.3.649>. Accessed: Apr. 27, 2018. doi: 10.1128/ AAC.45.3.649.

SULEIMAN, T. S. et al. Prevalence of bovine subclinical mastitis and antibiotic susceptibility patterns of major mastitis pathogens isolated in Unguja island of Zanzibar, Tanzania. Tropical Animal Health and Production, v.50, n.2, p.259266, 2018. Available from: <https://doi.org/10.1007/s11250017-1424-3>. Accessed: Apr. 18, 2018. doi: 10.1007/s11250017-1424-3.

TANJI, Y. et al. IgG-dependent aggregation of Staphylococcus aureus inhibits bacteriophage attack. Biochemical Engineering Journal, v.97, p.17-24, 2015. Available from: <https://doi. org/10.1016/j.bej.2015.01.007>. Accessed: Apr. 18, 2018. doi: 10.1016/j.bej.2015.01.007. 
TITZE, I. et al. Efficacy of bacteriophages against Staphylococcus aureus isolates from bovine mastitis. Pharmaceuticals, v.13, n.35, 2020. Available from: <https://doi.org/ 10.3390/ph13030035>. Accessed: Nov. 12, 2020. doi: 10.3390/ph13030035.

VEIGA-CRESPO, P., et al., What can bacteriophages do for us? In Communicating Current Research and Educational Topics and Trends in Applied Microbiology. In: A. MÉNDEZ-
VILAS A. SPAIN: FORMATEX; CENTER. (org.). p.885893. E-book.

XIA, G. et al. Wall teichoic acid-dependent adsorption of staphylococcal siphovirus and myovirus. Journal of Bacteriology, v.193, n.15, p.4006-4009, 2011. Available from: <https://doi. org/10.1128/JB.01412-10>. Accessed: Apr. 18, 2018. doi: 10.1128/ JB.01412-10. 